\title{
Diversification of an Endemic Southeast Asian Genus: Phylogenetic Relationships of the Spiderhunters (Nectariniidae: Arachnothera)
}

\author{
Author(s): Robert G. Moyle, Sabrina S. Taylor, Carl H. Oliveros, Haw Chuan Lim , Cheryl L. Haines ,
} Mustafa A. Rahman , and Frederick H. Sheldon

Source: The Auk, 128(4):777-788. 2011.

Published By: The American Ornithologists' Union

URL: http://www.bioone.org/doi/full/10.1525/auk.2011.11019

BioOne (www.bioone.org) is a nonprofit, online aggregation of core research in the biological, ecological, and environmental sciences. BioOne provides a sustainable online platform for over 170 journals and books published by nonprofit societies, associations, museums, institutions, and presses.

Your use of this PDF, the BioOne Web site, and all posted and associated content indicates your acceptance of BioOne's Terms of Use, available at www.bioone.org/page/terms_of_use.

Usage of BioOne content is strictly limited to personal, educational, and non-commercial use. Commercial inquiries or rights and permissions requests should be directed to the individual publisher as copyright holder. 


\title{
DIVERSIFICATION OF AN ENDEMIC SOUTHEAST ASIAN GENUS: PHYLOGENETIC RELATIONSHIPS OF THE SPIDERHUNTERS (NECTARINIIDAE: ARACHNOTHERA)
}

\author{
Robert G. Moyle, ${ }^{1,5}$ Sabrina S. Taylor $^{2}$ Carl H. Oliveros, ${ }^{1}$ Haw Chuan lim, ${ }^{3}$ \\ Cheryl L. Haines, ${ }^{3}$ Mustafa A. Rahman, ${ }^{4}$ and Frederick H. Sheldon ${ }^{3}$ \\ ${ }^{1}$ Biodiversity Institute and Department of Ecology and Evolutionary Biology, University of Kansas, Lawrence, Kansas 66045, USA; \\ ${ }^{2}$ School of Renewable Natural Resources, Louisiana State University Agricultural Center, Baton Rouge, Louisiana 70803, USA; \\ ${ }^{3}$ Museum of Natural Science and Department of Biological Sciences, Louisiana State University, Baton Rouge, Louisiana 70803, USA; and \\ ${ }^{4}$ Faculty of Resource Science and Technology, Universiti Malaysia Sarawak, 94300 Kota Samarahan, Sarawak, Malaysia
}

\begin{abstract}
The phylogeny of spiderhunters (Nectariniidae: Arachnothera) was reconstructed by comparing mitochondrial and nuclear DNA sequences of all currently recognized species and with broad geographic sampling of two particularly variable species complexes, the Little Spiderhunter (Arachnothera longirostra) and the streaky spiderhunters ( . modesta and $A$. affinis). It appears to be a relatively old group, whose diversification was not caused by recent sea-level changes. However, the modern, highly sympatric distribution of the large species in the Sunda lowlands was probably a result of dispersal via recent land bridges. Within the highly variable $A$. longirostra group, there are substantially diverged taxa in the Philippines that should be considered different species. Within the A. affinis-modesta complex, there are three distinct species and a closely related fourth, which describe a clear allopatric distribution: A. affinis in Java, A. modesta in the rest of the Sunda lowlands (except Sabah), A. magna in the Malayan highlands and mainland Southeast Asia, and $A$. everetti in the Bornean highlands and Sabah. Depending on whether mitochondrial or nuclear genes were compared, monophyly of the genus was disrupted by a single outgroup sunbird (Hypogramma hypogrammicum) or by all outgroup sunbirds included in the study. The discrepancy between nuclear and mitochondrial results is probably a case of deep coalescence and will require additional markers for resolution. Received 26 January 2011, accepted 16 August 2011.
\end{abstract}

Key words: Arachnothera, Nectariniidae, phylogeny, Southeast Asia, spiderhunters.

\section{Diversification d'un genre endémique de l'Asie du Sud-Est : les relations phylogénétiques d'Arachnothères (Nectariniidae : Arachnothera)}

RÉSUMÉ.-La phylogénie des Arachnothères (Nectariniidae : Arachnothera) a été construite en comparant les séquences d'ADN mitochondrial et nucléaire de toutes les espèces actuellement reconnues et avec un large échantillonnage géographique de deux complexes d'espèces particulièrement variables, soit Arachnothera longirostra ainsi qu'A. affinis-modesta. Il semble s'agir d'un groupe relativement ancien, dont la diversification n'a pas été causée par des changements récents du niveau de la mer. Cependant, la répartition moderne et hautement sympatrique de la grosse espèce dans les basses terres de Sunda était probablement le résultat de la dispersion via des ponts terrestres récents. Au sein du groupe hautement variable d'A. longirostra, il existe des taxons substantiellement différenciés aux Philippines qui devraient être considérés comme des espèces différentes. Pour le complexe $A$. affinis-modesta, il existe trois espèces distinctes et une quatrième étroitement apparentée, qui décrivent une répartition allopatrique claire : A. affinis à Java, $A$. modesta dans le reste des terres basses de Sunda (excepté Sabah), A. magna dans les hautes terres de Malaya et la partie continentale de l'Asie du Sud-Est, ainsi qu'A. everetti dans les hautes terres de Bornéo et Sabah. Selon que les gènes mitochondriaux ou nucléaires étaient comparés, la monophylie du genre était perturbée par un seul hors-groupe d'oiseaux (Hypogramma hypogrammicum) ou par tous les hors-groupes d'oiseaux inclus dans l'étude. L'écart entre les résultats nucléaires et mitochondriaux constitue probablement un cas de coalescence profonde qui requiert des marqueurs supplémentaires pour être résolu.

THE TWO MAJOR island groups of Southeast Asia, the Greater Sundas and the Philippines, have distinct biogeographic histories. The Greater Sundas are continental islands, but the Philippines are largely oceanic islands (Hall and Holloway 1998). With the exception of Palawan, which lies on the Sunda shelf, the Philippines were never connected to any other land mass and, thus, have been

${ }^{5}$ E-mail: moyle@ku.edu

The Auk, Vol. 128, Number 4, pages 777-788. ISSN 0004-8038, electronic ISSN 1938-4254. @ 2011 by The American Ornithologists' Union. All rights reserved. Please direct all requests for permission to photocopy or reproduce article content through the University of California Press's Rights and Permissions website, http://www.ucpressjournals. com/reprintInfo.asp. DOI: 10.1525/auk.2011.11019 
considerably more isolated than the Greater Sundas (Heaney 1986). Borneo, Sumatra, Java, their associated small islands, and the Malay Peninsula lie on the Sunda continental shelf. Much of the shelf is covered by a shallow sea that was exposed during periods of glaciation and low sea level in the Pleistocene, and the resulting large land mass known as Sundaland encompassed the islands and mainland of Southeast Asia (Whitmore 1987). Concomitant with low sea levels, colder climates and reduced oceanic effects caused montane forests in the region to descend to lower elevations (Flenley 1998, Cannon et al. 2009), thus forming barriers to lowland populations and corridors among previously isolated higher montane populations. The colder climate and drier conditions also caused savanna and seasonal forests to replace rainforest in interior lowland areas of Sundaland, thus further separating rainforest taxa into allopatric populations (Heaney 1991, Flenley 1998, Meijaard 2003, Bird et al. 2005, Cannon et al. 2009).

Recent molecular phylogenetic studies have begun to define distinct patterns of diversification within the Greater Sundas and Philippines that bear on potential connections and disconnections among populations (Gorog et al. 2004, Campbell et al. 2006, Jansa et al. 2006, Ryan and Esa 2006, Esselstyn and Oliveros 2010, Esselstyn et al. 2010). For birds, most phylogenetic work in the region has focused on Borneo, which is a key link between the Philippines and the Greater Sundas (Diamond and Gilpin 1983). Moyle et al. (2005) first documented a major genetic discontinuity within lowland Borneo that made populations of the White-crowned Forktail (Enicurus leschenaulti), a saxicoline thrush (Sangster et al. 2010), in Sarawak (northwest Borneo) more closely related to populations in Sumatra and the Malay Peninsula than to populations in Sabah (northeast Borneo). Subsequent work on additional lowland bird species has expanded the list of taxa that exhibit this pattern (Sheldon et al. 2009b; Lim et al. 2010, 2011). Studies of widespread Southeast Asian avian taxa have also found that Philippine populations tend to be more distinct genetically from their Sundaic relatives than previously thought. As such, they merit consideration as endemic Philippine species rather than simply polymorphic extensions of continental Southeast Asian species (Sheldon et al. 2009b; Lim et al. 2010, 2011; Lohman et al. 2010; Oliveros and Moyle 2010).

The genus Arachnothera, the spiderhunters, presents an excellent opportunity to examine these patterns further and investigate the processes responsible for avian diversification in Sundaland and the Philippines. Spiderhunters are members of the sunbird family (Nectariniidae) and include widespread as well as island endemic species across southern Asia, the Greater Sunda Islands, and portions of the Philippines (Fig. 1). They reach their greatest diversity on Borneo. Of the 10 currently recognized species (Dickinson 2003), seven are confined to Sundaland, one has a Sundaic as well as an Asian mainland population (A. magna), one ranges from mainland Southeast Asia across Sundaland and into the oceanic Philippines (A. longirostra), and one is confined to the oceanic Philippines (A. clarae). Morphological diversity among species is reflected by the number of subspecies (Dickinson 2003), from none (A. juliae, A. crassirostris, A. flavigaster) to 13 (A. longirostra). In morphology, spiderhunters are larger and heavier-bodied than other sunbirds, and like female sunbirds they usually have drab greenish, yellow, or gray plumage. One exception is Whitehead's Spiderhunter (A.juliae), an endemic of Bornean mountains that is dark brown with white streaks. All feed on nectar and small arthropods (not necessarily spiders).

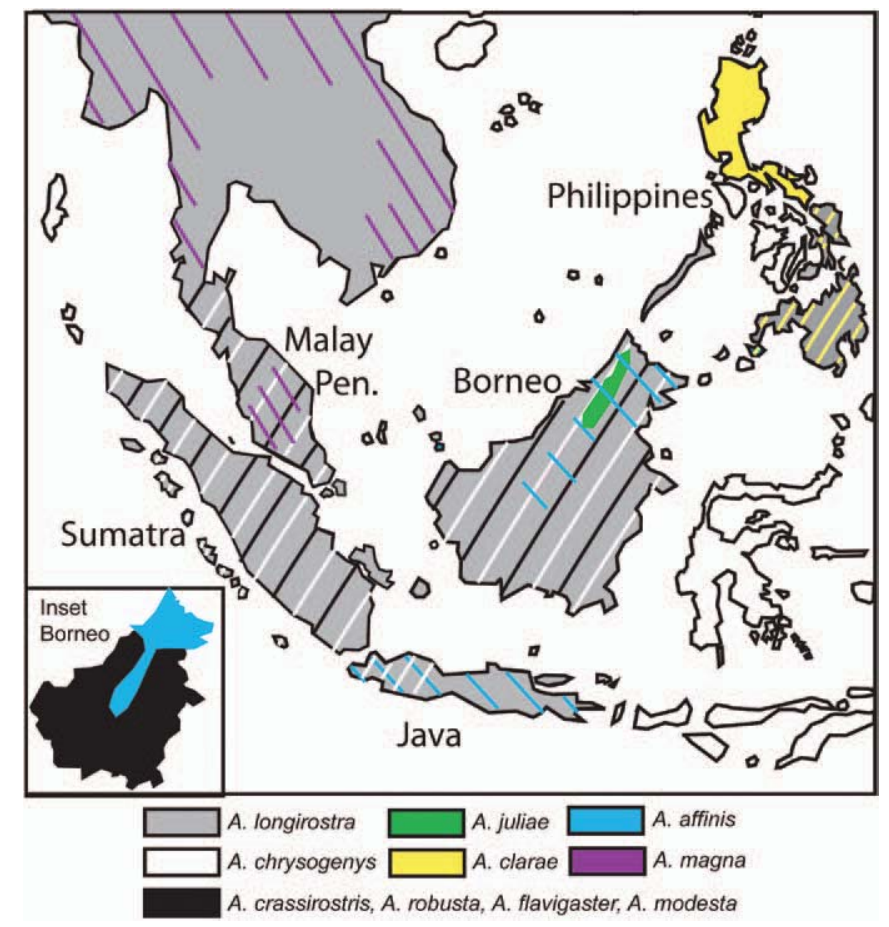

FIG. 1. Map of spiderhunter (Arachnothera) distributions in Southeast Asia from Cheke and Mann (2008) and Kennedy et al. (2000). The western extensions of Arachnothera longirostra in India and $A$. magna in the eastern Himalayas are not shown. The distribution of $A$. modesta extends farther north than shown, into far southwest Myanmar and Thailand. The inset provides a more precise estimate of the distribution of $A$. affinis and A. modesta on Borneo (Sheldon et al. 2001).

Two of the spiderhunter species complexes comprise considerable geographic variability and taxonomic uncertainty. The Little Spiderhunter (A. longirostra) is the most widespread species in the genus, ranging from India to the Philippines. Molecular phylogenetic comparisons have shown a deep genetic split between the population on Mindanao in the southern Philippines and populations in Sundaland and mainland Asia (Lohman et al. 2010, Rahman et al. 2010). Rahman et al. (2010) also found that the population on Palawan is distinct, even though Palawan is a Sundaic island adjacent to Borneo. Both of these studies included only mitochondrial DNA data and samples from single sites in the Philippines (Mindanao and Palawan). Here, we compare a larger number of $A$. longirostra populations using additional molecular markers to provide a broader biogeographic assessment of the species complex.

The complex consisting of $A$. affinis and A. modesta (hereafter "A. affinis-modesta complex") comprises five subspecies and is a group of large-bodied and variably streaky spiderhunters that occurs throughout Sundaland. Classification of the complex has been the subject of considerable debate, and opinions regarding the number, distribution, and rank of taxa vary substantially. Here, we attempt to resolve the uncertainty in their relationships and distribution by focusing primarily on the relationships of $A$. affinis everetti and $A$. modesta modesta on Borneo. Sharpe (1893) described $A$. everetti from the vicinity of Mt. Kinabalu (Sabah, 
Malaysian north Borneo) and considered it an endemic species because of its large size and heavy streaking. Over the next century, this taxon has variably been treated as a subspecies of an expanded $A$. affinis that also included all populations of $A$. modesta (e.g., Chasen 1935; Smythies 1957, 1960), as a Bornean endemic species (Stresemann 1938, Rand 1967, Sibley and Monroe 1990, MacKinnon and Phillipps 1993, Inskipp et al. 1996), or as a subspecies of a more narrowly circumscribed $A$. affinis that excluded A. modesta (lowland Borneo, Sumatra, and mainland Asia) (Davison 1999, Dickinson 2003, Mann 2008). The situation is further complicated because $A$. modesta appears not to occur in Sabah and $A$. affinis occupies both the lowlands and mountains in that part of Borneo (Chasen 1935; Sheldon et al. 2001, 2009a, b; Haines 2007). Nevertheless, birdwatchers frequently report the two species in sympatry in Sabah, and recent revisions continue to list two species in north Borneo (Cheke and Mann 2008, Mann 2008).

We compared DNA sequences of nuclear and mitochondrial genes from all described species of Arachnothera, including a broad geographic sample of the two widespread and variable species complexes (A. longirostra and $A$. affinis-modesta). Our main goals were to evaluate the taxonomic status of several populations and define species limits that accurately describe diversity in the genus, and then apply patterns evident in the phylogeny to shed light on the history of diversification of the spiderhunters and other similarly distributed groups of the Greater Sunda and Philippine islands.

\section{Methods}

Samples of spiderhunters were collected by us and others across southeast and southern Asia (Appendix). Sampling was most dense in Borneo and the Philippines to assess populations in the A. longirostra and A. affinis-modesta species complexes. The ingroup consisted of 46 individuals representing all species in the genus. Most samples were derived from modern specimens collected in the wild. However, ancient DNA of $A$. juliae and two populations in the A. affinis-modesta complex (A. affinis from Java and $A$. modesta from Sumatra) was extracted from museum study skins because no fresh samples were available. As outgroups, we included a selection of other sunbird and flowerpecker (Dicaeidae) genera. A leafbird (Chloropsis hardwickii) and a dipper (Cinclus pallasii) served as more distant outgroups to root trees.

Total genomic DNA from modern samples was extracted from frozen or alcohol-preserved muscle tissue using standard Qiagen extraction protocols (Qiagen, Valencia, California). Molecular markers consisted of sequences of the mitochondrial genes nicotinamide adenine dinucleotide dehydrogenase subunits 2 (ND2; 1,041 base pairs [bp]) and 3 (ND3; 351 bp), and the fifth nuclear intron of the transforming growth factor, $\beta 2$ (TGF $32 ; 549$ bp aligned). These were amplified using the primers L5215-H6313 (Hackett 1996, Johnson and Sorenson 1998), L10755-H11151 (Chesser 1999), and TGF5 and TGF6 (Primmer et al. 2002), respectively. Polymerase chain reaction [PCR] products were purified with ExoSAP-IT (US78201; Amersham Biosciences, Piscataway, New Jersey) or Qiagen Qiaquick PCR purification kits. Purified PCR products were then sequenced with ABI Prism BigDye Terminator chemistry, version 3.1 (Applied Biosystems, Foster City, California), using the same primers used for PCR. Cycle sequencing products were purified through Sephadex or precipitation in $70 \%$ ethanol and then analyzed on an ABI 134 Prism 3130xl Genetic Analyzer (Applied Biosystems). SEQUENCHER, version 4.7 (Gene Codes, Ann Arbor, Michigan), was used to reconcile complementary gene sequences and align sequences across taxa.

Ancient DNA was extracted in a clean lab dedicated to historical samples with strict protocols to prevent contamination. Historical samples were extracted with Qiagen kits using carrier RNA and multiple negative controls. In addition, DNA was eluted twice with $200 \mu \mathrm{L}$ of the provided buffer and both eluates were combined and concentrated to $\sim 100 \mu \mathrm{L}$ to increase DNA yield. Ancient DNA was amplified and, if necessary, reamplified with PCR product. The PCR product was verified on agarose gels and, if present, samples were cleaned with the Qiagen PCR Purification kit, cycle sequenced, and cleaned with Sephadex prior to sequencing on an ABI 3730 platform. Ancient DNA was sequenced at ND2 using the published primer sequences above as well as a series of short, overlapping primer pairs that were designed using a degenerate consensus sequence obtained from contemporary Arachnothera sequences. These short, degenerate internal primer pairs amplified consecutive 100-150 bp sections of the ND2 gene (see Table 1) and were also used in various combinations to amplify larger fragments. Sequence coverage for historical samples was approximately $6 \times$ and sequences within an individual were

TABLE 1. Sequences of newly designed primers for amplifying and sequencing ND2 from museum study-skin samples.

\begin{tabular}{|c|c|}
\hline Primer name & $5^{\prime}$ to $3^{\prime}$ sequence \\
\hline ND2Int1F & AACCCCMTAGCAAAASYA \\
\hline ND2Int1R & TTRATTTCTAGKCCGGYT \\
\hline ND2Int2F & ACWACYATYACAGTAWCRAGCA \\
\hline ND2Int2R & GRAAGTATTTRGTTGCGG \\
\hline ND2Int3F & CCAYCCVCGAGCYATTGA \\
\hline ND2Int3R & GRTGGGTTAGTTGGGTRA \\
\hline ND2Int4F & AGCATRACYAAYGCATGA \\
\hline ND2Int4R & TKACYGTGGATAGAAGRAG \\
\hline ND2Int5F & СТAGTMCCATTCCAYTTCT \\
\hline ND2Int5R & TGGGGTTKARTGATKGKG \\
\hline ND2Int6F & ATTCCCHCCWCTCACAYT \\
\hline ND2Int6R & GCKAGGATTTTTCGGATT \\
\hline ND2Int7F & TRGGMGGATGAATAGGAYT \\
\hline ND2Int7R & ATKAGYGAGTAYAGGTAGAAG \\
\hline ND2Int8F & CTCMTACRACCCYAAACT \\
\hline ND2Int8R & TYGCRTTTADRGATGGRRYT \\
\hline ND2Int9F & AMCCACMYTAATAACWGCA \\
\hline ND2Int9R & TAGGGAGAGYAGGGTTAG \\
\hline ND2Int10F & TACTAАСССТRCTCTCCC \\
\hline ND2Int10R & TTGYTTRGTYAGTTCYTGKAYG \\
\hline ND2Int11F & ACAGGATTCMTKCCYAAA \\
\hline ND2Int11R & GGCGKAGGTAGAAGAAYA \\
\hline ND2Int12F & ААТАКСССТАСТАТСУСТАС \\
\hline ND2Int12R & GRYWGGYTTRTTAGTRYG \\
\hline ND2Int13F & СССУССУСАYАСМАСААА \\
\hline ND2Int13R & TGKRTADATKAKKGGDGCVRT \\
\hline
\end{tabular}


verified to ensure that identical sequences were obtained for all combinations of published and internal primers.

Phylogenetic analysis was conducted using maximum likelihood (ML) implemented in the software RAXML, version 7.2.6 (Stamatakis et al. 2008). Sequences were divided into four partitions (three mitochondrial codon positions and the intron) and analyzed using the GTRGAMMA model of evolution. Clade support was evaluated with 1,000 fast bootstrap pseudoreplicates (Stamatakis et al. 2008). We also conducted Bayesian analysis (BA) using Markov chain Monte Carlo (MCMC) tree searches in MRBAYES, version 3.1.2 (Huelsenbeck and Ronquist 2001, Ronquist and Huelsenbeck 2003). MtDNA sequences were partitioned by codon positions, and the nuclear intron was treated as a separate partition. MRMODELTEST, version 2.3 (Nylander 2004), was used to determine the substitution model based on Akaike's information criterion. Two independent runs of 10 million generations were conducted with default chain heating conditions, sampling every 5,000 generations. Stationarity was evaluated with the program AWTY (Nylander et al. 2008) by plotting bipartition frequencies of each run in nonoverlapping bins of 500,000 generations ("Slide") and comparing the frequency of bipartitions between the two runs with various burnin proportions removed ("Compare"). Generations before the runs had stabilized and converged on similar posterior probabilities for clades were discarded as burn-in. The remaining trees were retained and summarized in a majority-rule consensus tree. Bayesian analyses were also conducted on the mitochondrial and nuclear data separately to examine congruence in phylogenetic signal between the two markers.

We examined the influence of missing data by plotting taxon stability against the proportion of missing data for each individual in MESQUITE (Maddison and Maddison 2010). This test has been useful in identifying taxa that cannot be placed with confidence because of missing data. For sample trees, we used bootstrap replicates from the maximum likelihood analysis.

\section{ReSULTS}

Sequence attributes.-The DNA sequence matrix contained 48 ingroup individuals from 10 species and 1,940 bases (1,041 ND2, 351 ND2, 549 TGF $\beta 2$ ), of which 703 (31.7\%) were parsimony informative (489 ND2, 138 ND3, 76 TGF $\beta 2$ ). Sequences derived from museum study skins were limited to ND2. All newly produced sequences are available from the GenBank database (accession numbers JF956831-JF956984). Aligned ND2 and ND3 sequences appeared to be of mitochondrial origin rather than nuclear copies, they contained no stop codons, overlapping fragments contained no conflicts, base composition was relatively homogeneous across taxa, codon positions contained expected relative divergences $(3>1>2)$, and resulting relationships contained no highly suspect arrangements. Base composition in the mitochondrial data was biased, with an excess of adenine and cytosine $(\mathrm{A}=0.307, \mathrm{C}=$ $0.339, \mathrm{G}=0.113, \mathrm{~T}=0.241$ ), but consistent with compositional patterns found in these genes in other bird groups (e.g., Sheldon et al. 2005, Moyle et al. 2007). Base composition in the intron data was more homogeneous $(\mathrm{A}=0.243, \mathrm{C}=0.234, \mathrm{G}=0.218, \mathrm{~T}=0.306)$. Models of evolution chosen for all likelihood analyses accounted for base composition bias. A chi-square test for homogeneity of base frequencies across taxa detected no significant differences for each gene (ND2, $P=0.93$; ND3, $P=1.0$; TGF $\beta 2, P=1.0$ ).

Aligned TGF $\beta 2$ sequences contained several inferred insertions or deletions (indels), but alignment of the sequences was fairly straightforward for two reasons. First, indels were infrequent enough that they generally did not overlap, allowing homologous indels to be identified. Second, the nucleotide sequences themselves were not highly diverged, which simplified alignment and default placement of indels. Shared indels included a 2-bp deletion in two individuals of both $A$. chrysogenys and $A$. clarae; a 2-bp deletion in two individuals of $A$. longirostra (14039 and 18123) and Nectarinia olivacea; a 1-bp insertion in the three individuals of Hypogramma; and a 3-bp deletion shared by all individuals of $A$. longirostra, A. rosbusta, A crassirostris, Anthreptes singalensis, Aethopyga christinae, Nectarinia olivacea, N. sperata, and Anthreptes rectirostris.

Phylogenetic results.-The taxon stability test revealed that samples with missing data were placed with the same, or more, consistency than samples with full data. The nine most unstable taxa were the nine samples of Arachnothera everetti. These samples had very similar sequences, and apparently changed relationships among bootstrap replicates, but were always recovered as a clade. Bayesian and ML analysis produced different topologies but they did not conflict at any well-supported nodes ( $>70 \%$ boostrap support and 0.95 posterior probability). However, analysis of each marker individually revealed conflicting phylogenetic signal between the nuclear and mitochondrial data. The description of relationships that follows is based on the ML topology of the combined data (Fig. 2). Differences in trees between the markers are shown in Figure 3 and are described following the discussion of general relationships of the spiderhunters. Combined data analysis recovered the Purple-naped Sunbird (Hypogramma hypogrammicum) inside Arachnothera, rendering the genus paraphyletic. Support for the node that includes Hypogramma within Arachnothera was fairly strong, with a Bayesian posterior probability of 0.97 and ML boostrapping support at $87 \%$. This node unites Hypogramma with clade A of the spiderhunters (Fig. 2). Clade A split into 2 subclades, one of which included the Bornean endemic A. juliae sister to a clade consisting of $A$. chrysogenys and the Philippine endemic A. clarae. All relationships within this subclade received strong support. Within the other A subclade, A. flavigaster branched basally, followed by $A$. magna. The A. affinis-modesta species complex was strongly supported as sister to A. magna and contained substantial geographic structure. It consisted of three lineages comprising individuals from Java, Sumatra-Sarawak, and the Bornean mountains and northeast Bornean lowlands. The Javan individual was sister to the other two clades with strong ML bootstrap support (90\%) and marginally significant posterior probability $(0.95)$.

The second clade of spiderhunters (Fig. 2; clade B) contains just three species. Strong nodal support united $A$. robusta and A. crassirostris as sister taxa, with $A$. longirostra as sister to both of them. Arachnothera longirostra divided into three distinct clades corresponding to samples from Palawan, the southern Philippines (Mindanao, Dinagat, and Bohol), and all non-Philippine areas included in the study. The southern Philippine clade was separated by a deep branch from the Palawan population and its 


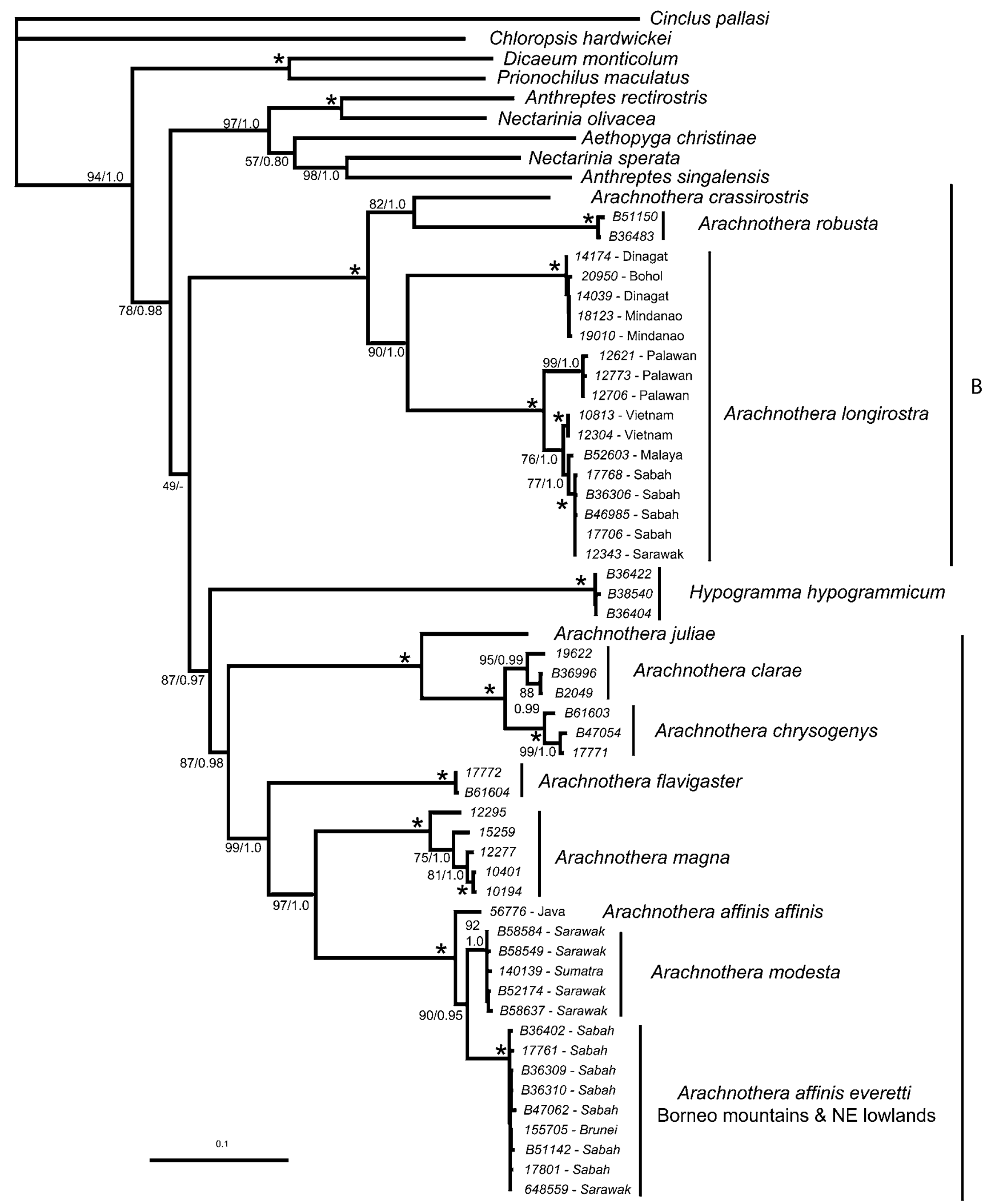

A

FIG. 2. Maximum-likelihood estimate of the spiderhunter phylogeny based on combined mitochondrial and nuclear sequences. Branch support numbers are bootstrap proportions/Bayesian posterior probability. Asterisks indicate 100\% bootstrap and 1.0 Bayesian support. 
well-defined sister, the non-Philippine populations. Within the latter, individuals from Borneo, Malaya, and Vietnam sorted into well-supported clades, although distinguished by shallow genetic divergences.

The main discrepancy between the nuclear and mitochondrial data concerned the placement of sunbirds other than $H y$ pogramma (i.e., Anthreptes singalensis, A. rectirostris, Nectarinia sperata, N. olivacea, and Aethopyga christinae). Mitochondrial data placed them solidly outside of Arachnothera, as expected. By contrast, the nuclear intron data placed them sister to clade B of Arachnothera with strong support. This relationship was further supported by a 3-bp deletion (Fig. 3). The conflict in phylogenetic signals likely contributed to the low support for Arachnothera (including Hypogramma) in the combined analysis. Support for $\mathrm{Hy}$ pogramma within Arachnothera derived mostly from the mtDNA data, which placed it clearly as sister to clade A (Fig. 3). The nuclear data placed Hypogramma in a polytomy with four other clades (Fig. 3).

Uncorrected proportional genetic distances ( $p$ distances) between samples can be used as a rough heuristic for divergence between lineages. For the ND2 data, A. longirostra individuals from Borneo were $0.6 \%$ diverged from the peninsular Malaysian individual, $1.3 \%$ diverged from the Vietnam birds, $5.2-5.5 \%$ from the Palawan birds, and about $16 \%$ from the southern Philippine clade. Individuals of $A$. affinis-modesta from the Bornean mountains and northeast lowlands were $4.5 \%$ diverged from Sumatran and Sarawak lowland birds, and 5.4\% diverged from the Javan bird. The Sumatran individual was only $0.3-0.6 \%$ diverged from multiple individuals from the Sarawak lowlands. The maximum divergence across five individuals of $A$. magna was almost $6 \%$, between a bird from Vietnam (12295) and samples from China, Myanmar, and Vietnam. Curiously, another individual (12277) collected from the same site on the same trip to Vietnam (P. Sweet pers. comm.) grouped with the samples from Myanmar and China. The cause of such a high divergence within this Vietnam population is unknown.

\section{Discussion}

Higher-level phylogeny.-Analysis of the nuclear and mitochondrial sequence data produced conflicting hypotheses about the relationships of Arachnothera. Although this conflict precluded reliable inference of some of the deeper relationships among major spiderhunter clades, most nodes among species received strong support from both markers, allowing us to discuss several aspects of spiderhunter taxonomy and hypotheses of avian diversification in the Sunda region.

Spiderhunters do not appear to be monophyletic. The Purple-naped Sunbird is nested inside Arachnothera and is the sister of one of the two main spiderhunter clades. Support for the novel phylogenetic placement of Hypogramma derives mostly from the mtDNA data; the intron places it in a polytomy with several other lineages (Fig. 2). This result is unexpected, given that we can find no mention of possible inclusion of Hypogramma within spiderhunters in the literature. In the only other molecular phylogenetic study that included both genera, Sibley and Ahlquist's (1990) DNA-DNA hybridization comparisons recovered Arachnothera and Hypogramma in a polytomy with the rest of the Nectariniidae. The nuclear data indicate that Arachnothera monophyly is further disrupted by the other sunbirds we included in the study as outgoups. Intron comparisons place the five sunbird species in a group that is sister to clade B of Arachnothera with high support (Fig. 3). The mtDNA data do not corroborate this relationship, but instead place the five other sunbirds outside of Arachnothera-Hypogramma. The latter arrangement seems most likely, given the many differences between ArachnotheraHypogramma and other sunbirds (see below). The incongruence between mitochondrial and nuclear genes may be a case of deep coalescence and gene tree-species tree discordance. More independent markers will need to be applied to this problem to resolve it.

A close relationship, or monophyly, of Hypogramma and Arachnothera is consistent with their distribution, morphology, and behavior. Hypogramma occurs in the same areas as Arachnothera (i.e., throughout much of Southeast Asia and the Greater Sundas, except Java). Both sexes of Hypogramma and several species of spiderhunters have varying degrees of underpart streaking. Such streaking occurs only in females of a few other sunbird species. Hypogramma's only overt plumage difference from spiderhunters is the small iridescent purple patch on the nape and rump of the male. Hypogramma constructs a purse-shaped nest typical of sunbirds, but it is suspended from the underside of a large leaf as in spiderhunters (Wells 2007, Cheke and Mann 2008). In spiderhunters, both parents incubate eggs, which is unusual in sunbirds. Hypogramma's incubation behavior is unknown. Hypogramma is smaller than several species of spiderhunters but is roughly the same size as $A$. longirostra and $A$. crassirostris. If this phylogenetic result is corroborated, we suggest that Hypogramma be subsumed within Arachnothera.

Higher-level relationships of spiderhunters are well resolved, but they do not indicate clear geographic or diversification patterns, except in the case of A. affinis, A. modesta, and A. magna. There are three groups of relatively closely related spiderhunter species: (1) A. affinis, A. modesta, A. magna, and A. flavigaster (Fig. 2; clade A); (2) A. clarae, $A$. chrysogenys, and $A$. juliae (Fig. 2; clade A); and (3) A. crassirostris, $A$. robusta, and $A$. longirostra (Fig. 2; clade $B$ ). The first consists of three medium-sized and one largesized species. The three medium-sized species-A. affinis, $A$. modesta, and $A$. magna - are all streaked, and they replace one another geographically. Where they co-occur, $A$. modesta inhabits the lowlands and A. magna (Malay Peninsula) or A. affinis (Borneo) occupies the highlands (but see below for more details on the taxonomy and distribution of $A$. affinis). This pattern suggests a species group that subdivided and then came into secondary contact. The second group consists of three medium-sized species. One of them is widespread in Sundaland (A. chrysogenys) and two are distributionally restricted endemics, $A$. clarae in the Philippines and A. juliae in the mountains of Borneo. This distribution is highly reminiscent of a clade of trogons in the genus Harpactes (Hosner et al. 2010), described below. The third group contains the two smallest spiderhunters, $A$. longirostra and A. crassirostris, as well as the somewhat larger but morphologically similar $A$. robusta.

Taxonomy of species groups.-Both genetic markers indicated deep divergences within $A$. longirostra that distinguished the two endemic Philippine taxa from all other Little Spiderhunter populations included in the study. The two Philippine taxa are the Palawan 


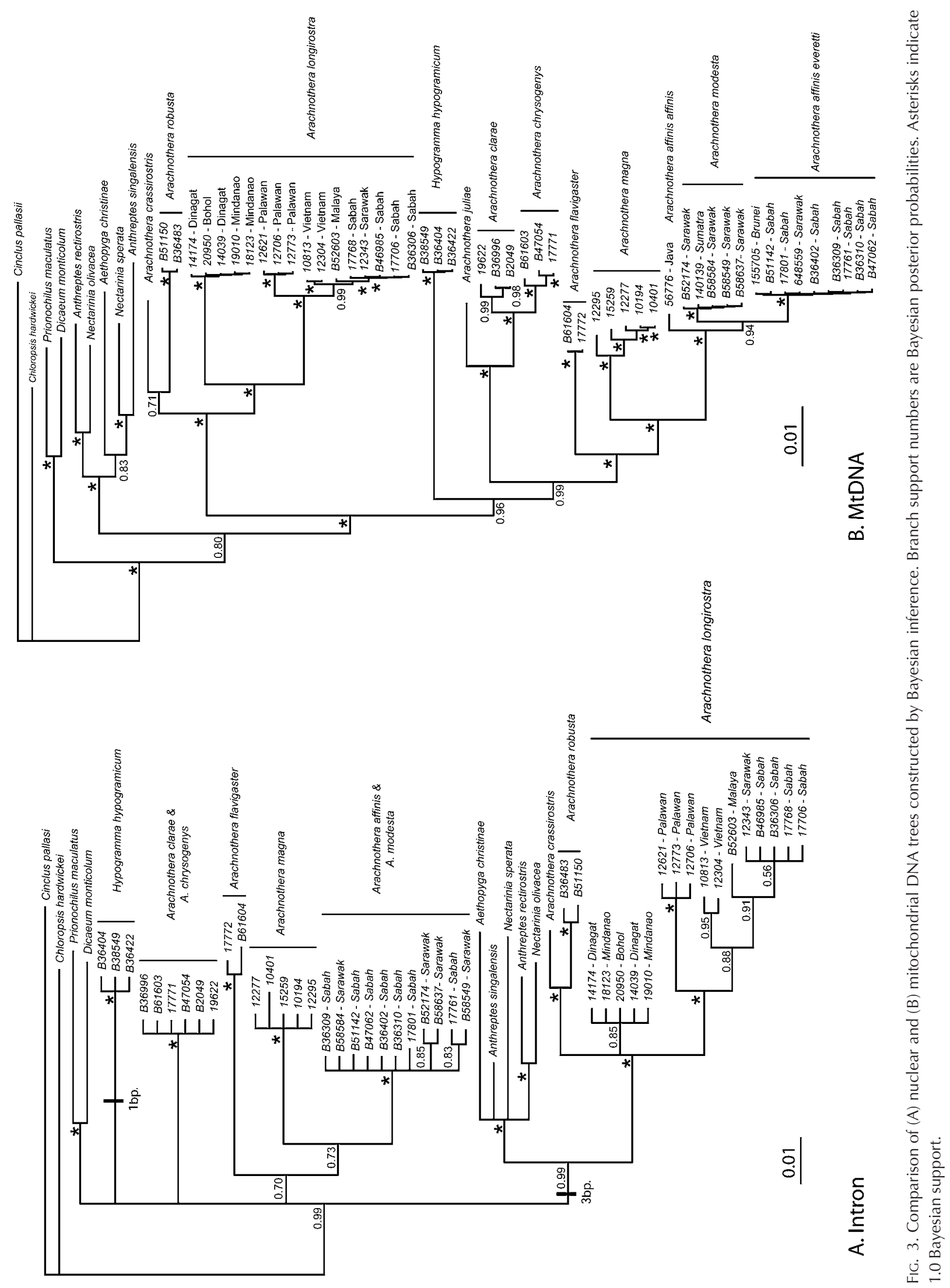


subspecies dilutior and the southern Philippine subspecies flammifera (and presumably randi from Basilan Island, which we did not sample). Their genetic distinctiveness was suggested earlier by Rahman et al. (2010) and Lohman et al. (2010), and for this reason we investigated them with expanded sampling. In addition to their molecular divergence, dilutior and flammifera are also morphologically distinct (Table 2). Subspecies dilutior has a yellow eye-ring that fades in museum specimens and is not depicted in field guides, although it is noted in the text by Kennedy et al. (2000). It is drabber than populations in neighboring Borneo, having almost no yellow in its underparts. Subspecies flammifera is small-bodied, and its yellow plumage is restricted to the lower abdomen, flanks, and vent. Both of the Philippine taxa lack light lores and eyebrows, typical of A. longirostra in Sundaland and continental Southeast Asia. As a result of molecular and morphological differences, the endemic Philippine little spiderhunters should be treated as two distinct species: A. dilutior Sharpe, 1876, on Palawan; and A. flammifera Tweeddale, 1878, on the southern Philippine islands. Within Borneo, no break appears between the birds of Sarawak and Sabah, as occurs in many other species (Moyle et al. 2005, Lim et al. 2011). Panmixia may be attributed to the high vagility of spiderhunters, which search widely for food and live in a variety of habitats.

Current taxonomy inaccurately reflects relationships within the $A$. affinis species complex. Arachnothera affinis, which includes

TABLE 2. Proposed species-level taxa of spiderhunters (genus Arachnothera) with descriptions and distributional information.

\begin{tabular}{|c|c|c|}
\hline Latin name & Description $^{\mathrm{a}}$ & Distribution \\
\hline A. dilutior & $\begin{array}{l}\text { Yellow eye-ring, drabber under- } \\
\text { parts than } A \text {. longirostra, no } \\
\text { light eyebrow or lores as in } \\
\text { A. longirostra }\end{array}$ & Palawan \\
\hline A. flammifera & $\begin{array}{l}\text { Small size, yellow restricted to } \\
\text { lower abdomen, flanks, and } \\
\text { vent; lacks light eyebrows and } \\
\text { lores of } A \text {. longirostra }\end{array}$ & $\begin{array}{l}\text { Southern Philippines } \\
\text { (Bohol, Dinagat, Leyte, } \\
\text { Mindanao, Samar, and } \\
\text { probably Basilan) }\end{array}$ \\
\hline A. everetti & $\begin{array}{l}\text { Large-bodied, with dark gray- } \\
\text { brown streaking from chin to } \\
\text { abdomen and flanks; streaks } \\
\text { more diffuse on abdomen; } \\
\text { dull yellow wash to abdomen, } \\
\text { marked sexual size dimor- } \\
\text { phism; wing (male) } 87-96 \text { mm } \\
\text { (mean } 91.2, n=14),(\text { female) } \\
\text { 78-85 mm (mean } 81.4, n=9 \text { ) }\end{array}$ & $\begin{array}{l}\text { Montane Borneo and } \\
\text { northeast lowland } \\
\text { Borneo }\end{array}$ \\
\hline A. affinis & $\begin{array}{l}\text { Similar to } A \text {. everetti, but with } \\
\text { rusty breast streaks; wing } \\
\text { (male) } 76-94 \mathrm{~mm} \text { (mean } 84.9, \\
n=8),(\text { female) } 80-85 \mathrm{~mm} \\
\text { (mean } 82.5, n=4)\end{array}$ & Java and Bali \\
\hline A. modesta & $\begin{array}{l}\text { Much smaller body, shorter bill, } \\
\text { and more lightly streaked } \\
\text { than } A \text {. everetti; wing (male) } \\
\text { 77-82 mm }(79.5, n=2)\end{array}$ & $\begin{array}{l}\text { Extreme southern } \\
\text { Myanmar and } \\
\text { Thailand, Peninsular } \\
\text { Malaysia, Sumatra, } \\
\text { lowland Borneo except } \\
\text { in the northeast }\end{array}$ \\
\hline
\end{tabular}

a Measurements of $A$. everetti and $A$. affinis are from Davison (1999). Measurement of $A$. modesta is of two Louisiana State University specimens from Mt. Pueh, western Sarawak.
A. a. affinis of Java and A. a. everetti of montane and northeast lowland Borneo, is not a natural group and should not be maintained. Although we predicted that these two taxa would be closely related because other montane Bornean bird species appear to have close Javan relatives (Sheldon et al. 2009a), this prediction proved to be wrong. Outside of Borneo, A. a. affinis and the widespread lowland A. modesta have at times been considered conspecific (Chasen 1935, Rand 1967), but lumping those taxa would also create a paraphyletic group. Instead, our comparisons defined three lineages, each of which should be considered distinct species. Arachnothera affinis should be split into $A$. affinis from Java and Bali and $A$. everetti from montane and northeast lowland Borneo. The constitution of $A$. $\bmod -$ esta (Davison 1999) remains largely unchanged. The lowland individuals that we compared from Sarawak in western Borneo were most similar to those from Sumatra, which suggests a strong Sundaic connection (Lim et al. 2011). Finally, there is no evidence that $A$. modesta occurs in Sabah. The seven individual streaky spiderhunters that we compared from Sabah, although derived from sites spanning 200$2,100 \mathrm{~m}$ in elevation, were all closely related to an individual from montane Sarawak rather than individuals from the lowlands of Sarawak or Sumatra. Future records from Sabah should be considered A. everetti unless evidence of $A$. modesta is thoroughly documented.

Diversification in the Sunda region.-Species of spiderhunters differ substantially at mitochondrial loci, and several have largely overlapping distributions (Fig. 1). These factors suggest that the forces behind the diversification of major groups of spiderhunters (and perhaps Hypogramma) are ancient and not the result of recent geological and environmental events such as the eustatic sea-level changes caused by Pleistocene glaciation. The widespread sympatry of most spiderhunter species in Sundaland (Fig. 1) suggests that, once diverged, these highly vagile birds took advantage of recent land bridges to move back and forth among islands (unfortunately, we did not have samples to examine genetic distances among populations on different Sunda islands). Another interesting aspect of spiderhunter distribution is that Sumatra lacks a montane specialist; this suggests that the montane taxa ( $A$. everetti and $A$. magna) did not make it that far south or west in Sundaland or went extinct there.

With respect to distribution and genetic divergence, the spiderhunters strongly resemble the trogons (Harpactes), another Asian group for which we have molecular phylogenetic data. Harpactes species have much the same distribution and their major clades are separated by long stem lineages that lead to several broadly sympatric species (Hosner et al. 2010). One trogon pattern is particularly reminiscent of the spiderhunters: a clade of three taxa consisting of one broadly distributed species (A. chrysogenys; H. kasumba), one Bornean mountain endemic (A. juliae; H. whiteheadi), and one Philippine endemic (A. clarae; H. ardens).

At the population level, we are beginning to see several variations on a common theme in Sundaland, in which populations in the lowlands of northeast Borneo are genetically (and sometimes morphologically) distinct from those in the lowlands elsewhere in Borneo (Moyle et al. 2005; Sheldon et al. 2009b; Lim et al. $2010,2011)$. These observations add to a growing body of evidence of a major biogeographic break within the island corresponding roughly with the border of Sabah (Gorog et al. 2004, Ryan and Esa 2006). The northern portion of Borneo's central highlands runs along the border between Sabah and Sarawak. This montane barrier, along with the isolating effects of a number of rivers 
that flow from the northern face of the central highland into the South China sea, could present a formidable dispersal impediment to lowland taxa. Interestingly, even when Sundaland was maximally exposed during glacial periods, little additional land connected Sabah to the rest of Borneo because of the deep waters around Sabah. Such insularity could further promote the differentiation of Sabah populations. Moyle et al. (2005) discovered the pattern of two lowland populations in the White-crowned Forktail but also found a third, more distant taxon (E. borneensis) in the mountains of Borneo. Moreover, the montane E. borneensis did not exhibit a biogeographic break corresponding to the lowland break. In the present study, we found a variation on this pattern. As in the forktails, the montane $A$. everetti is distinct from the lowland $A$. modesta, but there is no lowland population of $A$. modesta in Sabah; it is replaced there by $A$. everetti, which inhabits both montane and lowland areas. Whether the different genetic patterns among these species groups (three vs. two distinct Bornean lineages) indicate two distinct historical causes of diversification, or rather variation in the outcome of a single historical driver, is uncertain. Quite possibly, A. everetti was isolated in a northern Bornean rainforest refuge, as apparently were other lowland Sabahan birds (Lim et al. 2010, 2011). It maintained that lowland distribution in the absence of $A$. modesta and also expanded southward through the mountains, where $A$. modesta was absent. Alternatively, $A$. everetti was always a montane species that was able to expand into the lowlands of Sabah because of the absence of $A$. modesta, but not into the lowlands elsewhere in Borneo where $A$. modesta occurred. It is also possible that $A$. everetti once inhabited a broad elevational range across all of Borneo but has recently been displaced from the western lowlands by $A$. modesta.

\section{ACKNOWLEDGMENTS}

The following museums kindly provided tissue samples: University of Kansas Natural History Museum, Louisiana State University Museum of Natural Science, American Museum of Natural History (AMNH), and Cincinnati Museum Center. We particularly thank the AMNH, the Academy of Natural Sciences of Philadelphia, the Yale Peabody Museum, and the Western Foundation of Vertebrate Zoology for providing toe pad samples of inaccessible populations. For permission to undertake research in the Philippines, we thank the Department of Environment and Natural Resources of the Philippines and the Within Protected Areas and Wildlife Bureau. For research permission and assistance in Malaysia, we thank the Prime Minister's Department, the Chief Minister's Department of Sabah and Sarawak, the Sabah Wildlife Department, Sabah Parks, Sabah Museum, Sarawak Forest Department, Sarawak Forestry Corporation, Sarawak Biodiversity Institute, University Malaysia Sarawak, and Grand Perfect Sdn. Bhd. For assistance in the lab, we thank B. Cerame and M. Bowen. The research was funded by the Coypu Foundation, National Geographic Society, and the National Science Foundation (DEB-0228688 to F.H.S., DEB-0743491 and DEB0743576 to R.G.M.).

\section{Literature Cited}

Bird, M. I., D. Taylor, and C. Hunt. 2005. Palaeoenvironments of insular Southeast Asia during the last glacial period:
A savanna corridor in Sundaland? Quaternary Science Reviews 24:2228-2242.

Campbell, P., C. J. Schneider, A. M. Adnan, A. Zubaid, AND T. H. KunZ. 2006. Comparative population structure of Cynopterus fruit bats in peninsular Malaysia and southern Thailand. Molecular Ecology 15:29-47.

Cannon, C. H., R. J. Morley, and A. B. G. Bush. 2009. The current refugial rainforests of Sundaland are unrepresentative of their biogeographic past and highly vulnerable to disturbance. Proceedings of the National Academy of Sciences USA 106:11188-11193.

Chasen, F. N. 1935. A handlist of Malaysian birds. Bulletin of the Raffles Museum 11:1-389.

Cheke, R. A., And C. F. MAnn. 2008. Family Nectariniidae (sunbirds). Pages 196-320 in Handbook of the Birds of the World, vol. 13: Penduline-tits to Shrikes (J. del Hoyo, A. Elliott, and D. Christie, Eds.). Lynx Edicions, Barcelona, Spain.

Chesser, R. T. 1999. Molecular systematics of the rhinocryptid genus Pteroptochos. Condor 101:439-446.

Davison, G. W. H. 1999. Notes on the taxonomy of some Bornean birds. Sarawak Museum Journal 54:289-299.

DiAmond, J. M., AND M. E. GiLPIN. 1983. Biogeographic umbilici and the origin of the Philippine avifauna. Oikos 41:307-321.

Dickinson, E. C. 2003. The Howard and Moore Complete Checklist of the Birds of the World, 3rd ed. Christopher Helm, London.

Esselstyn, J. A., And C. H. Oliveros. 2010. Colonization of the Philippines from Taiwan: A multi-locus test of the biogeographic and phylogenetic relationships of isolated populations of shrews. Journal of Biogeography 37:1504-1514.

Esselstyn, J. A., C. H. Oliveros, R. G. Moyle, A. T. Peterson, J. A. MCGuire, And R. M. Brown. 2010. Integrating phylogenetic and taxonomic evidence illuminates complex biogeographic patterns along Huxley's modification of Wallace's Line. Journal of Biogeography 37:2054-2066.

Flenley, J. R. 1998. Tropical forests under the climates of the last 30,000 years. Climatic Change 39:177-197.

Gorog, A. J., M. H. Sinaga, And M. D. Engstrom. 2004. Vicariance or dispersal? Historical biogeography of three Sunda shelf murine rodents (Maxomys surifer, Leopoldamys sabanus and Maxomys whiteheadi). Biological Journal of the Linnean Society 81:91-109.

HACKeтt, S. J. 1996. Molecular phylogenetics and biogeography of tanagers in the genus Ramphocelus (Aves). Molecular Phylogenetics and Evolution 5:368-382.

Haines, C. L. 2007. Comparative phylogeography of four montane bird species in Sabah, Malaysian Borneo. M.S. thesis, Louisiana State University, Baton Rouge.

Hall, R., AND J. D. Holloway. 1998. Biogeography and Geological Evolution of SE Asia. Backhuys, Leiden, The Netherlands.

Heaney, L. R. 1986. Biogeography of mammals in SE Asia: Estimates of rates of colonization, extinction and speciation. Biological Journal of the Linnean Society 28:127-165.

HeAney, L. R. 1991. A synopsis of climatic and vegetational change in Southeast Asia. Climatic Change 19:53-61.

Hosner, P. A., F. H. Sheldon, H. C. Lim, And R. G. Moyle. 2010. Phylogeny and biogeography of the Asian trogons (Aves: Trogoniformes) inferred from nuclear and mitochondrial DNA sequences. Molecular Phylogenetics and Evolution 57:1219-1225.

Huelsenbeck, J. P., And F. RonQuist. 2001. MRBAYES: Bayesian inference of phylogenetic trees. Bioinformatics 17:754-755. 
InSkipp, T., N. LindSEy, AND W. DuCKWorth. 1996. An Annotated Checklist of the Birds of the Oriental Region. Oriental Bird Club, Bedfordshire, United Kingdom.

Jansa, S. A., F. K. Barker, And L. R. Heaney. 2006. The pattern and timing of diversification of Philippine endemic rodents: Evidence from mitochondrial and nuclear gene sequences. Systematic Biology 55:73-88.

Johnson, K. P., And M. D. Sorenson. 1998. Comparing molecular evolution in two mitochondrial protein coding genes (cytochrome $b$ and ND2) in the dabbling ducks (Tribe: Anatini). Molecular Phylogenetics and Evolution 10:82-94.

Kennedy, R. S., P. C. Gonzales, E. C. Dickinson, H. C. Miranda, And T. H. Fisher. 2000. A Guide to the Birds of the Philippines. Oxford University Press, New York.

Lim, H. C., M. A. Rahman, S. L. H. Lim, R. G. Moyle, and F. H. SHELDON. 2011. Revisiting Wallace's haunt: Coalescent simulations and comparative niche modeling reveal historical mechanisms that promoted avian population divergence in the Malay Archipelago. Evolution 65:321-334.

Lim, H. C., F. Zou, S. S. Taylor, B. D. Marks, R. G. Moyle, G. Voelker, And F. H. Sheldon. 2010. Phylogeny of magpierobins and shamas (Aves: Turdidae: Copsychus and Trichixos): Implications for island biogeography in Southeast Asia. Journal of Biogeography 37:1894-1906.

Lohman, D. J., K. K. Ingram, D. M. Prawiradilaga, K. Winker, F. H. SHeldon, R. G. Moyle, P. K. L. NG, P. S. ONG, L. K. WANG, T. M. Braile, AND others. 2010. Cryptic genetic diversity in "widespread" Southeast Asian bird species suggests that Philippine avian endemism is gravely underestimated. Biological Conservation 143:1885-1890.

MacKinnon, J., AND K. Phillipps. 1993. A Field Guide to the Birds of Borneo, Sumatra, Java, and Bali. Oxford University Press, Oxford, United Kingdom.

Maddison, W. P., AND D. R. MAdDison. 2010. MESQUITE: A modular system for evolutionary analysis. [Online.] Available at mesquiteproject.org.

Mann, C. F. 2008. The Birds of Borneo, an Annotated Checklist. British Ornithologists' Union and British Ornithologists' Club, Peterborough, United Kingdom.

MeIJAARD, E. 2003. Mammals of south-east Asian islands and their Late Pleistocene environments. Journal of Biogeography 30:1245-1257.

Moyle, R. G., J. Fuchs, E. PAsquet, And B. D. Marks. 2007. Feeding behavior, toe count, and the phylogenetic relationships among alcedinine kingfishers (Alcedininae). Journal of Avian Biology 38:317-326.

Moyle, R. G., M. Schilthuizen, M. A. Rahman, and F. H. SHELDON. 2005. Molecular phylogenetic analysis of the Whitecrowned Forktail Enicurus leschenaulti in Borneo. Journal of Avian Biology 36:96-101.

Nylander, J. A. A. 2004. MrModeltest, version 2. Program distributed by the author. Evolutionary Biology Centre, Uppsala University, Uppsala, Sweden. [Online.] Available at www.abc. se/ nylander/mrmodeltest $2 /$ mrmodeltest $2 . \mathrm{html}$.

Nylander, J. A. A., J. C. Wilgenbusch, D. L. WArRen, ANd D. L. SwOFFORD. 2008. AWTY (are we there yet?): A system for graphical exploration of MCMC convergence in Bayesian phylogenetics. Bioinformatics 24:581-583.

Oliveros, C. H., And R. G. Moyle. 2010. Origin and diversification of Philippine bulbuls. Molecular Phylogenetics and Evolution 54:822-832.
Primmer, C. R., T. Borge, J. Lindell, ANd G.-P. SÆtre. 2002. Single-nucleotide polymorphism characterization in species with limited available sequence information: High nucleotide diversity revealed in the avian genome. Molecular Ecology 11:603-612.

Rahman, M. A., D. F. A. Gawin, And C. Moritz. 2010. Patterns of genetic variation of the Little Spiderhunter (Arachnothera longirostra) in Southeast Asia. Raffles Bulletin of Zoology 58:381-390.

Rand, A. L. 1967. Family Nectariniidae. Pages 208-289 in Checklist of Birds of the World, vol. 12 (R. A. Paynter, Ed.). Museum of Comparative Zoology, Cambridge, Massachusetts.

Ronquist, F., And J. P. Huelsenbeck. 2003. MrBayes 3: Bayesian phylogenetic inference under mixed models. Bioinformatics 19:1572-1574.

RyAn, J. R. J., AND Y. B. EsA. 2006. Phylogenetic analysis of Hampala fishes (Subfamily Cyprininae) in Malaysia inferred from partial mitochondrial cytochrome $b$ DNA sequences. Zoological Science 23:893-901.

Sangster, G., P. Alström, E. Forsmark, And U. Olsson. 2010. Multi-locus phylogenetic analysis of Old World chats and flycatchers reveals extensive paraphyly at family, subfamily and genus level (Aves: Muscicapidae). Molecular Phylogenetics and Evolution 57:380-392.

Sharpe, R. B. 1893. Bornean notes. I. First list of birds from Mt. Kalulong, in Sarawak. II. A list of the birds collected by Mr. A. H. Everett on Mt. Penrisen and Mt. Poeh, in Sarawak. III. Description of a new Spilornis from Borneo. IV. A note on the Baza of Borneo. V. Notes on Mr. A. H. Everett's collections of birds from northern Borneo and Sarawak. VI. Additions to the avifauna of Mount Kina Balu. VII. Description of the nest and eggs of Staphidia everetti. Ibis 1893:546-563.

Sheldon, F. H., H. C. Lim, J. Nais, M. Lakim, A. Tuuga, P. Malim, J. Majuakim, A. Lo, M. Schilthuizen, P. A. HosNER, AND R. G. MoYLE. 2009a. Observations on the ecology, distribution, and biogeography of forest birds in Sabah, Malaysia. Raffles Bulletin of Zoology 57:577-586.

Sheldon, F. H., D. J. Lohman, H. C. Lim, F. Zou, S. M. Goodman, D. M. Prawiradilaga, K. Winker, T. M. Braile, AND R. G. MOYLE. 2009b. Phylogeography of the magpie-robin species complex (Aves: Turdidae: Copsychus) reveals a Philippine species, an interesting isolating barrier and unusual dispersal patterns in the Indian Ocean and Southeast Asia. Journal of Biogeography 36:1070-1083.

Sheldon, F. H., R. G. Moyle, and J. Kennard. 2001. Ornithology of Sabah: History, gazetteer, annotated checklist, and bibliography. Ornithological Monographs, no. 52.

Sheldon, F. H., L. A. Whittingham, R. G. Moyle, B. Slikas, AND D. W. Winkler. 2005. Phylogeny of swallows (Aves: Hirundinidae) estimated from nuclear and mitochondrial DNA sequences. Molecular Phylogenetics and Evolution 35:254-270.

Sibley, C. G., And J. E. Ahlquist. 1990. Phylogeny and Classification of Birds: A Study in Molecular Evolution. Yale University Press, New Haven, Connecticut.

Sibley, C. G., ANd B. L. Monroe, Jr. 1990. Distribution and Taxonomy of Birds of the World. Yale University, New Haven, Connecticut.

Smythies, B. E. 1957. An annotated checklist of the birds of Borneo. Sarawak Museum Journal 7:523-818.

Smythies, B. E. 1960. The Birds of Borneo. Oliver and Boyd, London.

Stamatakis, A., P. Hoover, and J. Rougemont. 2008. A fast bootstrapping algorithm for the RAxML web-servers. Systematic Biology 57:758-771. 
Stresemann, E. 1938. Vögel vomm Fluss Kayan (Nordost-Borneo). Temminckia 3:109-136.

Wells, D. R. 2007. The Birds of the Thai-Malay Peninsula, vol. 2: Passerines. Christopher Helm, London.
Whitmore, T. C., ED. 1987. Biogeographic Evolution of the Malay Archipelago. Clarendon Press, Oxford.

Associate Editor: J. P. Dumbacher

APPENDIX. Samples included in the study. Sources: Louisiana State University Museum of Natural Science (LSUMNS), University of Kansas Natural History Museum (KUNHM), American Museum of Natural History (AMNH), Cincinnati Museum Center (CMC), Academy of Natural Sciences Philadelphia (ANSP), and Western Foundation of Vertebrate Zoology (WFVZ). Asterisks indicate samples extracted from museum study skins, for which only ND2 was sequenced.

\begin{tabular}{|c|c|c|c|c|}
\hline Species & Locality & Elevation & Sample number & Collector-preparator \\
\hline \multirow[t]{16}{*}{ Arachnothera longirostra } & Crocker Range HQ, Sabah, Malaysia & $1,000 \mathrm{~m}$ & LSUMNS B36306 & R. G. Moyle \\
\hline & Serinsim, Sabah, Malaysia & $200 \mathrm{~m}$ & LSMMNS B46985 & R. G. Moyle \\
\hline & Bukit Hanta FR, Johor, Malaysia & $80 \mathrm{~m}$ & LSUMNS B52603 & H. C. Lim \\
\hline & Puerto Princesa, Palawan, Philippines & $200 \mathrm{~m}$ & KUNHM 12621 & C. H. Oliveros \\
\hline & Dinagat Island, Philippines & $200 \mathrm{~m}$ & KUNHM 14039 & R. Fernandez \\
\hline & Zamboanga, Mindanao, Philippines & $80 \mathrm{~m}$ & KUNHM 18123 & C. H. Oliveros \\
\hline & Puerto Princesa, Palawan, Philippines & $200 \mathrm{~m}$ & KUNHM 12706 & C. H. Oliveros \\
\hline & Mantalingajan Range, Palawan, Philippines & $850 \mathrm{~m}$ & KUNHM 12773 & R. G. Moyle \\
\hline & Dinagat Island, Philippines & $200 \mathrm{~m}$ & KUNHM 14174 & R. Fernandez \\
\hline & Bohol Island, Philippines & $350 \mathrm{~m}$ & KUNHM 20950 & C. H. Oliveros \\
\hline & Mt. Magdiwata, Mindanao, Philippines & $500 \mathrm{~m}$ & KUNHM 19010 & C. H. Oliveros \\
\hline & Penampang, Sabah, Malaysia & $375 \mathrm{~m}$ & KUNHM 17706 & R. G. Moyle \\
\hline & Ulu Kimanis, Sabah, Malaysia & $550 \mathrm{~m}$ & KUNHM 17768 & R. G. Moyle \\
\hline & Bintulu, Sarawak, Malaysia & $150 \mathrm{~m}$ & KUNHM 12343 & R. G. Moyle \\
\hline & Quang Nam, Vietnam & $200 \mathrm{~m}$ & AMNH DOT 10813 & P. R. Sweet \\
\hline & Quang Nam, Vietnam & $200 \mathrm{~m}$ & AMNH DOT 12304 & R. T. Chesser \\
\hline A. crassirostris & Kg. Pueh, Sarawak, Malaysia & $60 \mathrm{~m}$ & KUNHM 24436 & R. G. Moyle \\
\hline \multirow[t]{2}{*}{ A. robusta } & Mt. Trus Madi, Sabah, Malaysia & $1,400 \mathrm{~m}$ & LSUMNS B36483 & R. G. Moyle \\
\hline & Mt. Lucia, Sabah, Malaysia & $900 \mathrm{~m}$ & LSUMNS B51150 & B. D. Marks \\
\hline \multirow[t]{2}{*}{ A. flavigaster } & Ulu Kimanis, Sabah, Malaysia & $550 \mathrm{~m}$ & LSUMNS B61604 & F. H. Sheldon \\
\hline & Ulu Kimanis, Sabah, Malaysia & $550 \mathrm{~m}$ & KUNHM 17772 & R. G. Moyle \\
\hline \multirow[t]{3}{*}{ A. chrysogenys } & Serinsim, Sabah, Malaysia & $180 \mathrm{~m}$ & LSUMNS B47054 & R. G. Moyle \\
\hline & Ulu Kimanis, Sabah, Malaysia & $550 \mathrm{~m}$ & LSUMNS B61603 & F. H. Sheldon \\
\hline & Ulu Kimanis, Sabah, Malaysia & $550 \mathrm{~m}$ & KUNHM 17772 & R. G. Moyle \\
\hline \multirow[t]{3}{*}{ A. clarae } & Mindanao, Philippines & & СМС B2049 & R. S. Kennedy \\
\hline & Mindanao, Philippines & & СМС В36996 & R. S. Kennedy \\
\hline & Aurora, Luzon, Philippines & $525 \mathrm{~m}$ & KUNHM 19622 & C. H. Oliveros \\
\hline \multirow[t]{5}{*}{ A. modesta } & Kuching NP, Sarawak, Malaysia & Sea level & LSUMNS B52174 & H. C. Lim \\
\hline & Kg. Pueh, Sarawak, Malaysia & $50 \mathrm{~m}$ & LSUMNS B58549 & F. H. Sheldon \\
\hline & Kg. Pueh, Sarawak, Malaysia & $50 \mathrm{~m}$ & LSUMNS B58584 & F. H. Sheldon \\
\hline & Kg. Pueh, Sarawak, Malaysia & $50 \mathrm{~m}$ & LSUMNS B58637 & F. H. Sheldon \\
\hline & Meloewak, Sumatra & & ANSP 140139* & Vanderbilt Expedition \\
\hline A. affinis & Palabaeau Ratoe, West Java & & ANSP $56776^{*}$ & \\
\hline \multirow{9}{*}{ A. everetti } & Tawau Hills, Sabah, Malaysia & $300 \mathrm{~m}$ & LSUMNS B36402 & R. G. Moyle \\
\hline & Crocker Range HQ, Sabah, Malaysia & $1,000 \mathrm{~m}$ & LSUMNS B36310 & R. G. Moyle \\
\hline & Serinsim, Sabah, Malaysia & $180 \mathrm{~m}$ & LSUMNS B47062 & F. H. Sheldon \\
\hline & Mt. Lucia, Sabah, Malaysia & $1,000 \mathrm{~m}$ & LSUMNS B51142 & R. G. Moyle \\
\hline & Mt. Kinabalu, Sabah, Malaysia & $2,100 \mathrm{~m}$ & KUNHM 17801 & R. G. Moyle \\
\hline & Bario, Kelabit Plateau, Sarawak, Malaysia & $1,690 \mathrm{~m}$ & AMNH 648559* & T. Harrisson \\
\hline & Ulu Kimanis, Sabah, Malaysia & $550 \mathrm{~m}$ & KUNHM 17761 & R. G. Moyle \\
\hline & Temburong, Brunei & & LSUMZ 155705* & A. Chapman \\
\hline & Crocker Range HQ, Sabah, Malaysia & $1,000 \mathrm{~m}$ & LSUMNS B36309 & R. G. Moyle \\
\hline \multirow[t]{5}{*}{ A. magna } & Guanxi, China & $500 \mathrm{~m}$ & KUNHM 10401 & T. J. Davis \\
\hline & Guanxi, China & $978 \mathrm{~m}$ & KUNHM 10194 & A. Nyari \\
\hline & Kyi Tan, Myanmar & & KUNHM 15259 & F. Steinheimer \\
\hline & Quang Nam, Vietnam & $1,450 \mathrm{~m}$ & AMNH DOT 12277 & R. T. Chesser \\
\hline & Quang Nam, Vietnam & $1,450 \mathrm{~m}$ & AMNH DOT 12295 & R. T. Chesser \\
\hline A. juliae & Moyog, Sabah, Malaysia & $1,470 \mathrm{~m}$ & WFVZ $41711^{*}$ & D. Foote \\
\hline
\end{tabular}


ApPendix. Continued.

\begin{tabular}{|c|c|c|c|c|}
\hline Species & Locality & Elevation & Sample number & Collector-preparator \\
\hline \multicolumn{5}{|c|}{ Outgroups } \\
\hline Anthreptes singalensis & Klias Forest Reserve, Sabah, Malaysia & $20 \mathrm{~m}$ & LSUMNS B47156 & B. D. Marks \\
\hline A. rectirostris & Equatorial Guinea & & KUNHM 8499 & L. A. Sánchez-González \\
\hline Aethopyga christinae & Guanxi, China & $500 \mathrm{~m}$ & KUNHM 10276 & M. B. Robbins \\
\hline Nectarinia sperata & Ulu Tungud FR, Sabah, Malaysia & $100 \mathrm{~m}$ & LSUMNS B57444 & R. G. Moyle \\
\hline N. olivacea & Cameroon & $650 \mathrm{~m}$ & LSUMNS B27073 & D. Dittmann \\
\hline Hypogramma hypogrammicum & Tawau Hills, Sabah, Malaysia & $150 \mathrm{~m}$ & LSUMNS B36404 & R. G. Moyle \\
\hline H. hypogrammicum & Tawau Hills, Sabah, Malaysia & $150 m$ & LSUMNS B36422 & R. G. Moyle \\
\hline H. hypogrammicum & Tawau Hills, Sabah, Malaysia & $150 \mathrm{~m}$ & LSUMNS B38549 & R. G. Moyle \\
\hline Dicaeum monticolum & Meligan Range, Sabah, Malaysia & $1,600 \mathrm{~m}$ & KUNHM 17745 & R. G. Moyle \\
\hline Prionochilus maculatus & Bintulu, Sarawak, Malaysia & $150 \mathrm{~m}$ & KUNHM 12405 & R. G. Moyle \\
\hline Chloropsis hardwickei & Guanxi, China & $978 \mathrm{~m}$ & KUNHM 10019 & A. T. Peterson-A. Nyari \\
\hline Cinclus pallasii & China & & KUNHM 11241 & B. W. Benz \\
\hline
\end{tabular}

